NUSANTARA : Jurnal Ilmu Pengetahuan Sosial - Vol. 6 No 1 (2019) (Januari - Juni )

issn online : $2550-0813$ issn cetak : $2541-657 \mathrm{X}$

http://jurnal.um-tapsel.ac.id/index.php/nusantara

\title{
PERILAKU MEMILIH MASYARAKAT, MALPRAKTIK PEMILU DAN PELANGGARAN PEMILU
}

\author{
Ferdian $^{1)}$, Asrinaldi ${ }^{2)}$, Syahrizal ${ }^{3)}$ \\ ferdianpessel@gmail.com \\ ${ }^{1)}$ Magister Konsentrasi Tata Kelola Pemilu, FISIP, Universitas Andalas \\ ${ }^{2,3)}$ Pascasarjana Konsentarasi Tata Kelola Pemilu FISIP Universitas Andalas
}

\begin{abstract}
Abstrak
Perilaku memilih seseorang dalam pemilihan umum dipengaruhi oleh berbagai variabel seperti agama, ras, daerah, dan suku yang dikelompokkan oleh Lazarsfeld dalam mashab sosiologis, orientasi kepada kandidat dan identifikasi kepartaian yang termasuk dalam mashab psikologis, oleh Angust Campbel, dan kepentingan ekonomi dalam mashab rational atau ekonomi yang dipelopori oleh Anthony Downs. Perilaku memilih masyarakat di setiap daerah memiliki karakteristik yang berbeda-beda. Terdapat beberapa karakteristik perilaku memilih yang dapat menimbulkan terjadinya malpraktik dan pelanggaran pemilu khususnya vote buying atau politik uang.
\end{abstract}

Kata Kunci : Perilaku memilih, malpraktik pemilu, pelanggaran pemilu, vote buying, politik uang.

\section{Pendahuluan}

Demokrasi identik dengan pelaksanaan kekuasaan dari rakyat, oleh rakyat, dan untuk rakyat, dan juga diartikan sebagai rakyat berkuasa atau "government or rule by the people" (Miriam Budiardjo, 2005). Dalam sistem politik yang demokratis, rakyat mempunyai hak untuk memilih para wakilnya, baik yang duduk di parlemen, memilih pemimpin yang akan memerintah negara, dan mempunyai hak untuk terlibat aktif dalam kontestasi politik itu sendiri. Robert A Dahl (2001) mengatakan bahwa terdapat lima hal pokok dalam demokrasi, yaitu: kesempatan untuk partisipasi yang efektif, persamaan dalam memberikan suara, mendapatkan pemahaman yang jernih, melaksanakan pengawasan akhir terhadap agenda, dan pencakupan orang dewasa. Sedangkan Afan Gaffar (2006) menyatakan adanya rotasi kekuasaan dan dilaksanakannya pemilihan umum secara teratur, adalah syarat suatu negara dikatakan menganut sistem yang demokratis. Salah satu bentuk rotasi kekuasaan dan pemilihan umum yang dilaksanakan secara teratur di Indonesia adalah pemilihan Gubernur dan Wakil Gubernur, Bupati dan Wakil Bupati, serta Walikota dan Wakil Walikota yang merupakan pelaksanaan kedaulatan rakyat di wilayah provinsi dan kabupaten/kota. Pemilihan umum sering disebut sebagai pesta rakyat, ajang dimana rakyat menentukan pilihan tentang siapa yang akan mewakilinya, sekaligus pembaruan kontrak politik antara wakil dan yang diwakili (Khairul Fahmi. 2016).

Pelaksanaan demokrasi dapat dilihat melalui penggunaan hak pilih 
NUSANTARA : Jurnal Ilmu Pengetahuan Sosial - Vol. 6 No 1 (2019) (Januari - Juni )

issn online : $2550-0813$ issn cetak : 2541-657X

http://jurnal.um-tapsel.ac.id/index.php/nusantara

universal dalam pemilu, dimana setiap warga negara yang memenuhi persyaratan berhak untuk menggunakan hak pilihnya. Hal ini selaras dengan penjelasan yang diberikan oleh C.B Macpherson (1973) bahwa "One of the central value of our democratic theory has been the surpassing importance of freedom and choice". Perilaku memilih menjadi kajian menarik, karena berbagai faktor turut mempengaruhi pemilih dalam menentukan pilihannya. Faktor tersebut diantaranya seperti faktor kedaerahan / daerah asal calon, identifikasi kepartaian / kedekatan pemilih dengan partai pengusung calon, dan program-program pasangan calon yang dianggap akan memberikan keuntungan bagi mereka jika si calon terpilih, dan faktor agama. Meyer (2004) mengatakan bahwa kebudayaan berbasis agama dipengaruhi praktik kebiasaan beragama.

Perilaku memilih juga sering dipengaruhi dengan pemberian dari calon yang lazim disebut vote buying atau politik uang. Dibutuhkan suatu analisa yang menghubungkan fenomena-fenomena perilaku memilih, baik yang terjadi di dalam atau di luar individu. Asrinaldi (2012) menyatakan bahwa dengan menghubungkan variabel-variabel yang ada dalam perilaku memilih, dapat diketahui mengapa seseorang melakukan tindakan politik, sementara yang lain tidak. Dengan mengetahui perilaku memilih di suatu daerah, juga berguna bagi partai politik untuk melakukan pemetaan pemilih yang merupakan fondasi dalam mendesain kampanye kompetisi elektoral yang efektif dan efisien (Sigit Pamungkas, 2012).
Dalam beberapa penelitian sebelumnya, seperti penelitian di Kabupaten Pesisir Selatan yang dilakukan oleh Aidinil Zetra, Bakaruddin Rosyidi, Ferra Yanuar, dan Canang Bagus Prahara Umpu pada tahun 2015 dengan judul Partisipasi Politik dan Politik Uang dalam Pemilu Legislatif 2014 di Kabupaten Pesisir Selatan. Penelitian ini menemukan terdapat 3 (tiga) variabel yang mempengaruhi pemilih dalam pemilu yakni suku bangsa, kecamatan dan tingkat pendidikan. Dan dari hasil penelitian ditemukan fakta, sebanyak 69,6\% masyarakat di Kabupaten Pesisir Selatan menerima politik uang. Pada penelitian masyarakat adat Kurai di tahun 2017, Heldo Aura menyatakan bahwa ikatan primordial masih sangat berpengaruh terhadap perilaku pemilih. Hal ini dapat dilihat dari ketaatan masyarakat Kurai kepada adat istiadat dan tokoh masyarakat (niniak mamak, cadiak pandai dan alim ulama). Kemudian Adhi Putra Wicaksono di tahun 2009 dengan judul Perilaku Pemilih dalam Pemilihan Kepala Daerah Langsung: Studi Penelitian pada Pemilihan Gubernur/Wakil Gubernur Jawa Tengah Tahun 2008. Penelitian ini menemukan bahwa citra kandidat, identifikasi kepartaian dan efektifitas kampanye tidak memiliki pengaruh signifikan terhadap perilaku memilih.

Penelitian-penelitan diatas menunjukkan karakteristik pemilih di beberapa daerah di Indonesia yang belum berperilaku rasional dalam menentukan pilihan pada pemilu. Pemilu yang irrasional memiliki dampak buruk terhadap pemerintahan, jika kandidat yang kemudian terpilih merupakan kandidat yang tidak berkualitas. Pengamat politik Lembaga Ilmu Pengetahuan Indonesia 
NUSANTARA : Jurnal Ilmu Pengetahuan Sosial - Vol. 6 No 1 (2019) (Januari - Juni )

issn online : $2550-0813$ issn cetak : $2541-657 \mathrm{X}$

http://jurnal.um-tapsel.ac.id/index.php/nusantara

(LIPI), $\quad$ Syamsuddin Haris mengungkapkan bahwa Pemilu dalam terminologi demokrasi seharusnya berbasis pada rasionalitas. Haris menambahkan, bahwa irrasionalitas pemilihan dapat diatasi dengan pendidikan politik yang rasional dan politik kewarganegaraan, agar demokrasi di Indonesia tidak mengalami kemunduran.

(https://nasional.kompas.com/read/201 7/05/03/21150201/politik.identitas.me ngubur.rasionalitas.pemilih).

\section{Metode Penelitian}

Dalam penelitian ini penulis mempergunakan metode studi perpustakaan atau Library Resarch. Metode Library Research yaitu dengan mengambil dari berbagai buku, jurnal dan hasil penelitian terdahulu yang berkaitan dengan permasalahan yang hendak dibahas dan dicari jawabannya dan kemudian mengambil kesimpulan.

\section{Pembahasan dan Hasil}

\section{Perilaku Memilih : Pendekatan Teori}

Menurut Miriam Budiardjo (2008), teori adalah bahasan dan generalisasi dari suatu fenomena. Ada dua fungsi teori dalam ilmu politik, yakni : pertama, sebagai dasar norma atau moral bagi perilaku politik termasuk bagi penyelenggaraan kehidupan negara. Kedua, sebagai alat analisis atau tools of analysis dari fenomena-fenomena politik yang terjadi (Riaty Raffiudin, dkk. 2012). Perilaku memilih adalah bentuk dari partisipasi pemilu atau partisipasi politik, dan merupakan bentuk partisipasi yang paling elementer dalam demokrasi.
Menurut Ramlan Surbakti
(2007), perilaku pemilih adalah akivitas pemberian suara oleh individu yang berkaitan erat dengan kegiatan pengambilan keputusan untuk memilih atau tidak memilih di dalam suatu pemilihan umum (Pemilukada secara langsung). Perilaku memilih ini dipengaruhi oleh berbagai faktor yang tidak dapat berdiri sendiri, faktor yaitu faktor internal dan eksternal dari pemilih. sementara itu, Huntington dan Nelson (1990) menyebutkan perilaku memilih sebagai electoral activity, yakni termasuk pemberian suara (votes), bantuan untuk kampanye, bekerja dalam suatu pemilihan, menarik masuk atas nama calon, atau tindakan lain yang direncanakan untuk mempengaruhi proses pemilihan umum. Sedang menurut Jack Plano (1985), perilaku memilih adalah salah satu bentuk perilaku politik yang terbuka. Dalam mempelajari permasalahan terkait perilaku pemilih, peneliti mengacu kepada beberapa pendekatan atau mashab. Tiga mashab yang paling dominan digunakan dalam memahami perilaku memilih adalah mashab sosiologis, mashab psikologis dan mashab ekonomi (Asrinaldi, 2012).

\section{Mashab Sosiologis}

Mashab sosiologis muncul lebih dahulu dari dua mashab lainnya. Mashab sosiologis diyakini bersumber dari Eropa, sehingga juga sering disebut sebagai model sosiologi politik Eropa. Mashab ini dimulai oleh peneliti dari Biro Penerapan Ilmu Sosial Universitas Columbia seperti Lazarsfeld, Berelson dan Gaudet, sehingga disebut sebagai mashab Columbia. Hasil penelitian mereka yang terkenal yaitu: The People Choice : How The Voter Makes Up 
NUSANTARA : Jurnal Ilmu Pengetahuan Sosial - Vol. 6 No 1 (2019) (Januari - Juni )

issn online : $2550-0813$ issn cetak : $2541-657 \mathrm{X}$

http://jurnal.um-tapsel.ac.id/index.php/nusantara

His Mind In A Presidential Campaign (1944) dan Voting (1952). Mashab ini menjelaskan, bahwa perilaku politik seseorang dipengaruhi oleh faktorfaktor sosiologis. Faktor sosial ekonomi, orang tua, kedaerahan atau etnis, pekerjaan, agama, tempat tinggal, jenis kelamin dan usia memiliki pengaruh yang sangat signifikan dalam menentukan perilaku memilih. Ramlan Surbakti (2007) menyatakan, pendekatan sosiologis melihat latar belakang demografi dan sosial ekonomi seperti jenis kelamin, tempat tinggal, pekerjaan, pendidikan, kelas, pendapatan dan agama, berpengaruh dalam menentukan pilihan politik seseorang pada pemilihan umum. Mashab ini juga melihat adanya pengaruh identifikasi kelas sosial, yakni kesamaan cara pandang antara pemilih yang memiliki kedudukan sosial tertentu dengan kedudukan sosial partai politik. Atau hal tersebut ada diantara kedudukan sosial dirinya, dengan kedudukan sosial kandidat presiden dan wakil presidennya (P. Anthonius Sitepu, 2007). Gerald Pomper (1978:195-208) mengatakan bahwa pengaruh pengelompokkan sosial dalam studi perilaku memilih ada dua variabel, yaitu variabel predisposisi sosial ekonomi keluarga pemilih dan predisposisi sosial ekonomi pemilih. Terdapat hubungan antara pilihan politik keluarga dengan pilihan politik anak dalam keluarga tersebut.

Faktor kedaerahan ternyata sangat mempengaruhi pilihan seseorang dalam menentukan siapa calon yang akan dipilihnya. Penelitian Petterson dan Rose (1996) mengatakan bahwa ikatan-ikatan kedaerahan, seperti desa-kota, merupakan faktor yang cukup signifikan dalam menjelaskan aktifitas dan pilihan politik seseorang. Jadi bisa dikatakan bahwa mashab sosiologis melihat lingkungan mempengaruhi nilai dan keyakinan politik seseorang. Proses sosialisasi politik yang diterima oleh seseorang dimulai dari lingkungan keluarga, ditandai dengan terbentuknya latar belakang sosiologis dan karakteristik afiliasi orang tua, seperti nampak pada gambar berikut :

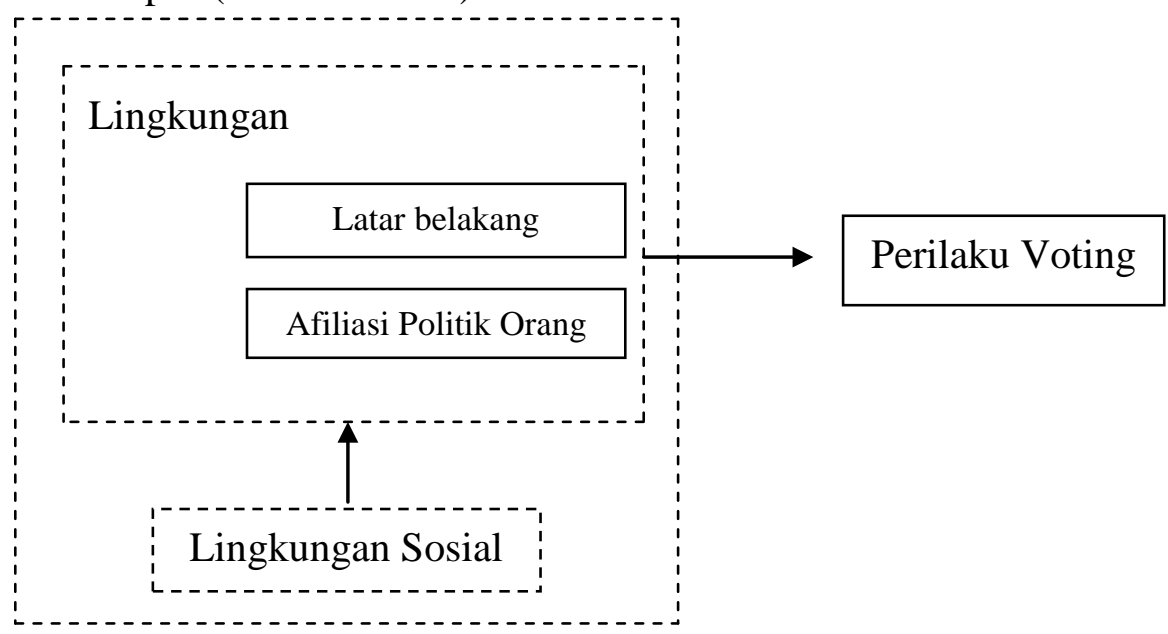

Gambar 2.1 : Model Pendekatan Sosiologis

2. Mashab Psikologis

Jika mashab sosiologis berasal

dari Eropa, mashab psikologis 
NUSANTARA : Jurnal Ilmu Pengetahuan Sosial - Vol. 6 No 1 (2019) (Januari - Juni )

issn online : $2550-0813$ issn cetak : $2541-657 \mathrm{X}$

http://jurnal.um-tapsel.ac.id/index.php/nusantara

merupakan fenomena Amerika Serikat karena dikembangkan sepenuhnya oleh ilmuwan di Amerika Serikat melalui Survey Research Centre di Universitas Michigan. Oleh karena itu mashab ini juga disebut sebagai mashab Michigan. Pelopor utama pendekatan ini adalah Angust Campbell. Dalam mashab ini menggunakan dan mengembangkan konsep psikologi untuk menjelaskan konsep perilaku pemilih. Menurut pendekatan ini, sosialisasi sangat menentukan perilaku memilih seseorang.

Mashab ini merupakan bentuk ketidakpuasan terhadap mashab sosiologis. Mashab sosiologis dianggap sulit diukur secara metodologis, misalnya tentang bagaimana mengukur secara tepat indikator struktur sosial, agama, pendidikan dan banyak indikator lainnya. Mashab sosiologis dianggap tidak dapat menjelaskan pola perilaku yang ada pada seseorang terutama terkait kedekatannya dengan suatu partai dan dianggap tidak memperhatikan adanya preferensi seseorang dalam menilai janji suatu partai politik atau calon dalam pemilihan. Apalagi, pendekatan sosiologis umumnya hanya sebatas menggambarkan dukungan suatu kelompok tertentu pada suatu partai politik, tidak sampai pada penjelasan mengapa suatu kelompok tertentu memilih atau mendukung suatu partai politik tertentu sementara yang lain tidak (Richard G. Niemi, Herbert F. Weisberg, 1984). Penganut mashab psikologis mengatakan bahwa sikap seseorang merupakan variabel yang cukup menentukan dalam mempengaruhi sikap politik seseorang. Variabel sikap seseorang tersebut diantaranya seperti identifikasi kepartaian, orientasi kepada kandidat, dan orientasi kepada isu-isu.

Hal yang disorot dalam mashab ini adalah bagaimana persepsi pemilih terhadap partai-partai politik yang ada atau bagaimana hubungan emosional pemilih dengan partai politik tertentu. Fiorina (1981) menyatakan pilihan seseorang terhadap partai politik tertentu melalui proses psikologis panjang, namun putusan akhir individu tersebut sangat bergantung kepada penilaiannya terhadap perkembangan politik kontemporer. Hal inilah yang kemudian memunculkan identifikasi partai atau kedekatan kepada suatu partai. Di dalam pemilihan kepala daerah, kedekatan kepada suatu partai ini bisa dilakukan dengan memilih calon yang didukung oleh partai yang dekat dengan individu tersebut. Adanya isuisu yang beredar di masyarakat juga menjadi faktor menentukan di dalam mashab psikologis ini, walaupun terkadang isu yang berkembang ini dibuat oleh suatu pihak untuk dapat menggiring opini masyarakat dan bisa juga sebagai pencitraan dari seorang calon. Faktor ketiga yaitu orientasi kepada kandidat. Didalam pemilihan kepala daerah yang biasanya hanya diikuti oleh sedikit pasangan calon maka orientasi kandidat ini berperan penting, dimana pemilih biasanya melihat dari sisi popularitas, reputasi dan kemampuan dari calon yang bersangkutan.

Hubungan dari ketiga variabel diatas terkait perilaku memilih, dapat dilihat dari gambar berikut: 
NUSANTARA : Jurnal Ilmu Pengetahuan Sosial - Vol. 6 No 1 (2019) (Januari - Juni )

issn online : $2550-0813$ issn cetak : $2541-657 \mathrm{X}$

http://jurnal.um-tapsel.ac.id/index.php/nusantara

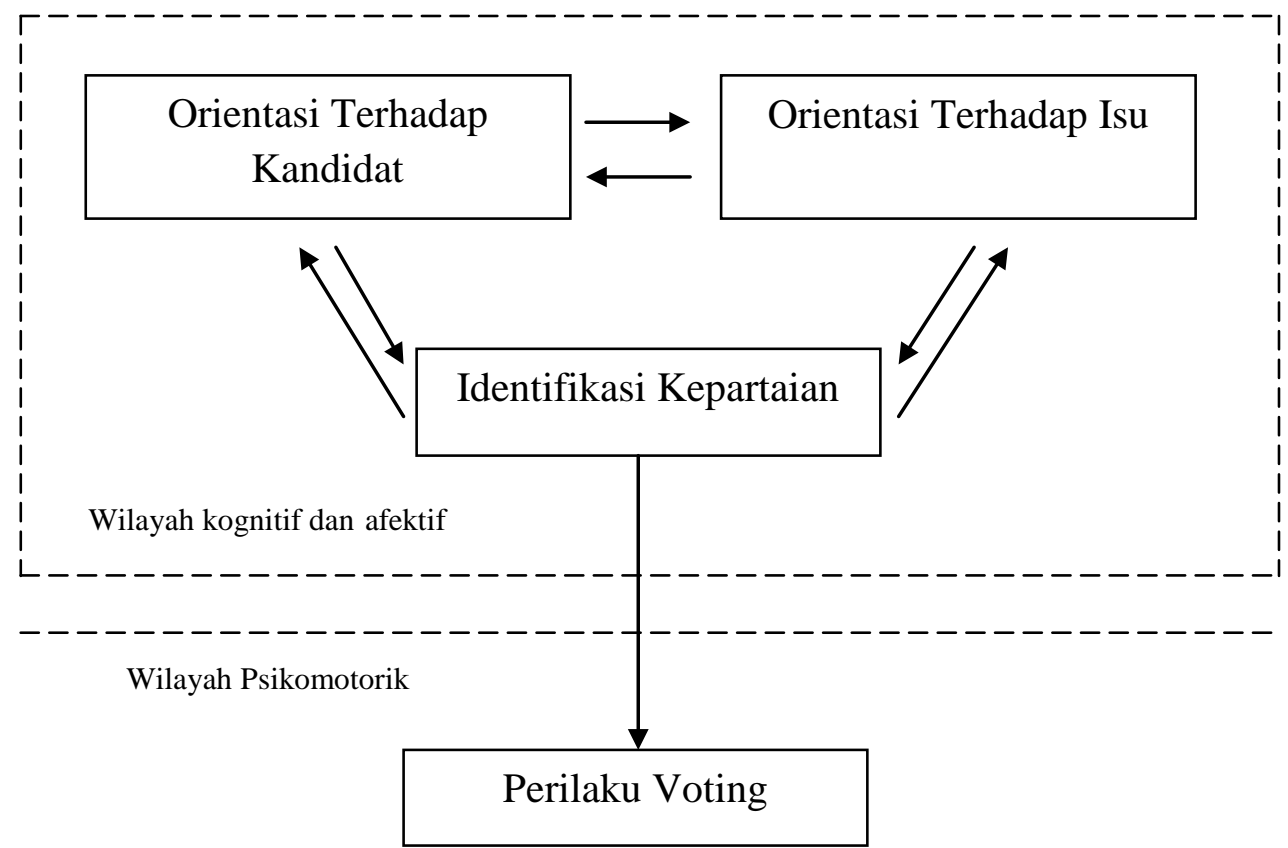

Gambar 2.2 : Model Pendekatan mashab Psikologis

\section{Mashab Rasional atau Ekonomi}

Mashab ini menempatkan pemilih pada posisi yang aktif, tidak pasif seperti pada mashab sosiologis dan psikologis. Faktor-faktor situasional dianggap menentukan atau ikut menentukan dalam mempengaruhi perilaku memilih seseorang. Mashab ini dipelopori oleh Anthony Down yang menggunakan asumsi teori ekonomi modern dalam buku An Economic Theory of Voting pada tahun 1957 sehingga disebut mashab ekonomi.

$\begin{array}{llr}\text { Dalam menjelaskan } & \text { perilaku } \\ \text { memilih, mashab } & \text { rasional } \\ \text { menganalogikan pasar ekonomi }\end{array}$
dengan perilaku memilih. Asumsi dasar dari mashab ini adalah bahwa individu cenderung bertindak rasional, yaitu memaksimalkan keuntungan dan meminimalkan kerugian yang didapat dari tindakan yang diambilnya. Lau \& Redlawsk menjelaskan "the approch is explicity normative in its orientation, describing how decision makers ought to behave to guarantee value-maximizing decisions".

Hastie \& Dawes (2001) mengkategorikan keputusan seseorang itu dianggap rasional jika :

1. Pilihan keputusan yang dibuat tersebut berdasarkan kepada keadaan status quo yang mereka miliki, dan kalaupun harus kehilangan aset yang dimiliki, maka mereka akan mendapatkan ganti yang seimbang.

2. Pilihan keputusan yang dibuat tersebut memberi hasil yang nyata kepada pembuat keputusan.

3. Keputusan yang dibuat itu tidak melanggar prinsip dasar yang menyebabkan peluang ketidak pastian dari keputusan tersebut menjadi besar atau mengancam apa yang ingin diperolehnya. 
NUSANTARA : Jurnal Ilmu Pengetahuan Sosial - Vol. 6 No 1 (2019) (Januari - Juni )

issn online : $2550-0813$ issn cetak : $2541-657 \mathrm{X}$

http://jurnal.um-tapsel.ac.id/index.php/nusantara

Perilaku memilih berdasarkan pertimbangan rasional tidak hanya berupa memilih alternatif yang paling menguntungkan atau mendatangkan keraguan yang paling sedikit. Tetapi juga dalam hal memlih alternatif dengan resiko yang paling kecil. Dengan begitu asumsi pemilih mempunyai kemampuan untuk menilai isu-isu politik yang diajukan (Muhamad Asfar, 2007). Didalam pemilihan kepala daerah, rasionalitas pemilih bisa terlihat dari terpilihnya kembali calon petahana yang dianggap dapat meningkatkan taraf ekonomi masyarakat. Sebaliknya, masyarakat akan mencari alternatif calon yang lain jika mereka menganggap calon petahana tidak memberikan efek apapun bagi mereka terutama dalam meningkatkan perekonomian. Dengan demikian maka calon penantang harus memiliki program yang dapat diterima oleh masyarakat dan dapat mengatasi permasalahan yang ada sebelumnya. Fiorina (1981) menyatakan rasionalitas pemilih harusnya tidak hanya terbatas kepada aspek pemenuhan kepentingan ekonomi individu saja, tetapi harus dalam skala yang lebih besar.

Aspek rasionalitas pemilih dalam mashab ekonomi ini dapat dilihat dalam gambar berikut:

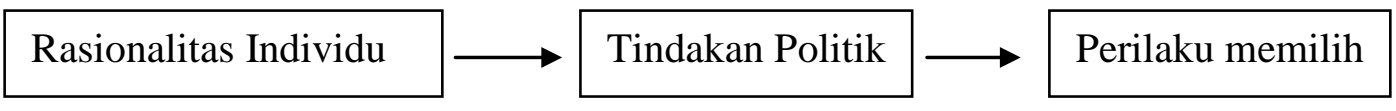

Kepentingan pribadi

Meminimumkan ketidak pastian

Memaksimalkan keuntungan

Rasional

Gambar 2.3 : Model pendekatan mashab ekonomi

\section{Malpraktik Pemilu dan Pelanggaran Pemilu}

Jika dikaji secara konsep, maka malpraktik pemilu (electoral malpractice) dapat didefinisikan sebagai penyimpangan penyelenggaraan pemilu dari normanorma pemilu yang berlaku umum, yang mengandung 3 (tiga) dimensi pelanggaran yaitu manipulasi peraturan tatakelola pemilu, manipulasi preferensi suara, dan manipulasi proses pemilihan (Kris Nugroho, 2014). Sarah Birch (2007) menyatakan bahwa malpraktik pemilu dianggap sebagai pelanggaran terhadap norma-norma ideal penyelenggaraan pemilu yang lazim yang terkait dengan pihak-pihak yang memiliki akses terhadap manipulasi tata kelola pemilu. Sedangkan pelanggaran pemilu dikonsepkan sebagai electoral misconduct yang digunakan untuk menjelaskan praktikpraktik manipulasi pemilu seperti pemaksaan suara, menghalangi pemberian suara, memilih berulang kali dan mengancam penyelenggara pemilu. Pelanggaran pemilu dianggap 
NUSANTARA : Jurnal Ilmu Pengetahuan Sosial - Vol. 6 No 1 (2019) (Januari - Juni )

issn online : $2550-0813$ issn cetak : $2541-657 \mathrm{X}$

http://jurnal.um-tapsel.ac.id/index.php/nusantara

memiliki makna yang lebih luas, yakni semua aktivitas yang melanggar prinsip pemilu yang demokratis dan mengarah pada tindakan kriminal. Sedangkan contoh malpraktik pemilu seperti pengelolaan administrasi pemilu yang merugikan pemilih, petugas yang tidak melakukan pendataan pemilih secara valid, yang disebabkan oleh kelalaian, kelelahan, kecerobohan atau ketidakmampuan dari petugas tersebut.

Pelanggaran pemilu dapat diklasifikasikan kedalam 4 (empat) macam. Pertama, pelanggaran administratif pemilu yang memiliki dampak pemilih tidak dapat menggunakan hak pilihnya. Hal ini dapat berimplikasi pada malpraktik pemilu karena dianggap melanggar prinsip kesamaan (equality) hak bagi setiap warga negara untuk didaftar sebagai pemilih. Kedua, pelanggaran pidana pemilu seperti vote buying atau politik uang, jual beli formulir C6 (surat pemberitahuan untuk memilih), menghalangi orang lain dalam memberikan suara, penggunaan kekerasan, dan perusakan sarana pemilu. Ketiga, pelanggaran dalam proses pemilu. Keempat, pelanggaran kode etik pemilu oleh penyelenggara pemilu yang penindakannya dilakukan oleh Dewan Kehormatan Penyelenggara Pemilu (DKPP). Secara garis besar, malpraktik pemilu dan pelanggaran pemilu dapat terjadi pada tahapan sebelum hari pemungutan suara, pada hari pemungutan suara, dan pada tahapan pemungutan dan penghitungan suara.

\section{Hubungan Perilaku Memilih Masyarakat Dengan Malpraktik dan Pelanggaran Pemilu}

Perilaku memilih masyarakat ternyata juga mendorong terjadinya malpraktik dan pelanggaran pemilu. Kasus yang paling sering terjadi adalah vote buying atau politik uang. Fenomena ini kebanyakan terjadi di negara berkembang dimana masyarakat dalam memilih calon masih berdasarkan rasionalitas ekonomi. Vote buying dapat diartikan sebagai penggunaan uang oleh peserta pemilu untuk kepentingan penambahan suara peserta pemilu (Jensen dan Justesen, 2013). Sasaran dari vote buying adalah pemilih atau penyelenggara pemilu yang dilakukan oleh peserta pemilu. Praktik vote buying ini dipengaruhi perilaku memilih masyarakat di daerah tersebut, misalnya pada perilaku memilih masyarakat yang cenderung dipengaruhi oleh mashab sosiologis, dimana karateristik sosiologi masyarakatnya dipengaruhi oleh pola relasi yang dominan patronklien maka proses pembelian suara dilakukan oleh jaringan klentalisme politik. Jaringan klientalistik ini berpusat pada tokoh dominan yang ditopang oleh struktur sosial yang sangat bergantung dan patuh pada sang tokoh (Hopkin, 2006). Vote buying dengan memanfaatkan patron atau tokoh masyarakat digunakan untuk membeli suara pemilih.

Dalam realitas pemilu di Indonesia, praktik vote buying ini merupakan tindakan yang biasa. Hal ini membuat berbagai pihak menjadi mencemaskan akan berlangsungnya demokratisasi di Indonesia. Vote buying marak terjadi disebabkan masyarakat Indonesia yang menentukan pilihannya berdasarkan pada rationalitas ekonomi yang instan dengan mengaitkan perilaku yang mereka lakukan dengan mashab 
NUSANTARA : Jurnal Ilmu Pengetahuan Sosial - Vol. 6 No 1 (2019) (Januari - Juni )

issn online : $2550-0813$ issn cetak : $2541-657 \mathrm{X}$

http://jurnal.um-tapsel.ac.id/index.php/nusantara

rasional atau ekonomi yang bertolak dari pandangan ekonomi klasik bahwa manusia merupakan makluk yang rasional dan bertindak berdasarkan pertimbangan untung dan rugi. Namun, rasionalitas yang berdasarkan untung dan rugi ini sering diartikan salah oleh pemilih. Mereka seringkali beranggapan bahwa tindakan mereka dalam melegalkan vote buying seperti menerima uang, bantuan dan hadiah dari partai politik atau kandidat merupakan tindakan rational dikarenakan mereka mendapatkan keuntungan secara ekonomi. Padahal menurut mashab rational atau ekonomi, pemberian suara oleh pemilih ini tidak berhenti pada hari pemungutan suara itu saja, namun memiliki konsekuensi jangka panjang, baik kepada diri pribadi pada saat pemungutan suara dilakukan dan juga masa depannya. Jadi seharusnya, suara yang mereka berikan tersebut paling tidak berdampak bagi diri mereka sendiri sebagai pemilih.

\section{Kesimpulan}

Perilaku memilih masyarakat dalam pemilu pada umumnya dipengaruhi oleh 3 (tiga) mashab yakni sosiologis, psikologis dan rational atau ekonomi. Ketiga pola perilaku memilih ini ternyata rawan menimbulkan malpraktik dan pelanggaran pemilu khususnya praktik vote buying atau politik uang. Hal ini terjadi karena dalam konteks perilaku memilih, tidak semua orang dapat menentukan keputusan politik mereka untuk sesuatu yang ingin diperolehnya setelah keputusan itu dibuat (untuk kepentingan jangka panjang). Aspek penting yang mempengaruhi rationalitas pemilih adalah tingkat pendidikan. Jika pemilih memiliki tingkat pendidikan yang rendah, maka vote buying akan sangat mungkin terjadi, karena hitung-hitungan ekonomi yang dibuat oleh pemilih hanya terbatas pada keadaan sesaat saja padahal efek dari suara yang mereka berikan sangat besar. Tingkat vote buying yang cukup tinggi juga dipengaruhi oleh perilaku elit (Ali Sahab, 2012). Elit yang sudah menduduki posisi kekuasaan kebanyakan tidak memperhatikan konstituennya. Hal tersebut menjadikan perilaku memilih masyarakat sebagian besar didasarkan pada keuntungan ekonomi yang mereka dapat dari para kandidat. Senada dengan itu Himmelweit dalam Consumer Mode of Party mengatakan pengambilan keputusan yang dilakukan oleh pemilih cenderung dilakukan secara instan, dan tergantung pada kondisi politik tertentu, tidak berbeda dengan pengambilan keputusan lainnya.

Dari pemaparan diatas, dapat kita ambil kesimpulan perilaku memilih di Indonesia cenderung terpapar dengan vote buying, apapun alasan masyarakat menentukan pilihan, vote buying tetap tampak dalam setiap pratik pemilu atau pilkada. Padahal rationalitas pemilih sangat dibutuhkan untuk mendapatkan hasil pemilu yang baik. Pemilih sangat diharapkan untuk dapat memilih kandidat berdasarkan visi dan misi, atau apa dampak jangka panjang dalam memilih calon tersebut sehingga kandidat yang terpilih merupakan kandidat yang berkualitas. Masyarakat yang merelakan suara mereka untuk dibeli, memutuskan menjual suara mereka kepada partai politik atau kandidat melalui sistematika patronklien, dapat dikategorikan sebagai pemilih yang 
NUSANTARA : Jurnal Ilmu Pengetahuan Sosial - Vol. 6 No 1 (2019) (Januari - Juni )

issn online : $2550-0813$ issn cetak : $2541-657 \mathrm{X}$

http://jurnal.um-tapsel.ac.id/index.php/nusantara

tidak rational, karena mereka hanya mengutamakan faktor ekonomi pribadi daripada kepentingan ekonomi nasional secara sistem untuk mendapatkan keuntungan dari pemberian suara yang dilakukan.

\section{Saran}

Dari pola perilaku memilih masyarakat dan kebiasaan vote buying dalam setiap pelaksanaan pemilu maupun pilkada, penulis memberikan saran agar pola ini tidak lagi terulang lagi atau paling tidak untuk meminimalisir terjadinya pola perilaku memilih yang sangat terpengaruh oleh vote buying. Pertama, setiap stakeholder pemilu (KPU, Bawaslu, dan Partai Politik) harus meningkatkan perannya dalam melakukan pendidikan kepada pemilih. Pemilih harus disadarkan dan dicerdaskan akan pentingnya suara yang mereka berikan pada hari pemungutan suara serta efek dari pemberian suara yang mereka lakukan untuk jangka panjang. Komisi Pemilihan Umum (KPU) dan Badan Pengawas Pemilu (Bawaslu) harus dapat besinergi, dimana KPU berperan dalam pemberian materi kepemiluan dan pendidikan pemilih, dan Bawaslu melakukan pengawasan dengan sungguh-sungguh agar tidak ada lagi pemanfaatan pola perilaku pemilih yang berujung pada malpraktik dan pelanggaran pemilu. Partai politik sebagai aktor utama dalam setiap pemilihan, harus mau melakukan pembenahan dalam internalnya masing-masing. Kandidat yang diusung oleh partai politik harus benar-benar orang yang telah diseleksi oleh partai politik itu sendiri, tidak boleh lagi kandidat yang akan dicalonkan berdasarkan orang yang mendaftar sewaktu pemilu akan dilaksanakan saja, karena kandidat yang seperti ini cenderung tidak mengetahui visi dan misi partai yang mengusungnya sehingga banyak yang menggunakan jalan pintas untuk mendapatkan suara pemilih. Jika kandidat dari partai politik yang akan menjadi calon lebih mengutaman visi, misi dan program dalam menarik suara pemilih, tentu praktik vote buying akan hilang dengan sendirinya. Terakhir, masyarakat sebagai pemilih tentu harus pula mau untuk menolak segala bentuk praktik vote buying yang dilakukan oleh para calon, jangan lagi menggunakan slogan "ambil uangnya dan tidak pilih calonnya" melainkan "tolak uangnya dan tidak pilih calonnya" sehingga calon yang melakukan praktik vote buying mendapatkan hukuman dengan tidak dipilih dalam pemilu maupun pilkada.

\section{Daftar Pustaka}

Asfar, Muhamad. (2007). Pemilu dan Perilaku Memilih 1955-2004 . Surabaya: Pustaka Eureka.

Asrinaldi. (2012). Politik Masyarakat Miskin Kota. Yogyakarta : Gava Media.

Aura, Heldo. (2017). Perilaku Pemilih Masyarakat Adat Kurai pada Pemilu Legislatif Tahun 2014.

Budiardjo, Miriam. (2005). Dasar-dasar Ilmu Politik. Jakarta : Gramedia Pustaka Utama.

Dahl, Robert A. (2001), Perihal Demokrasi: Menjelajahi Teori dan Praktek Demokrasi Secara Singkat. Terjemahan A Rahman Zainuddin, Jakarta:YOI 
NUSANTARA : Jurnal Ilmu Pengetahuan Sosial - Vol. 6 No 1 (2019) (Januari - Juni )

issn online : $2550-0813$ issn cetak : $2541-657 \mathrm{X}$

http://jurnal.um-tapsel.ac.id/index.php/nusantara

Fahmi, Khairul. (2016). Pemilihan Umum dalam Transisi Demokrasi. Jakarta : RajaGrafindo Persada.

Gaffar, Afan. (2006). Politik Indonesia : Transisi Menuju Demokrasi. Jakarta : Pustaka Pelajar.

Huntington, Samuel P. dan Nelson W.Polsby. (1990). Partisipasi Politik di Negara Berkembang. Jakarta: Rineka Cipta.

Macpherson, C.B. (1973). Democratic Theory essays in retrieval. Clarendon Press. Oxford. hal 3.

Meyer, Thomas. (2004). Politics of Identity: The Challenge Of Modern Fundamentalism dalam Politik Identitas. Jakarta: FES -Pemuda Muhammdiyah. hal. 85- 87

Mujani, Saiful, R. William Liddle, dan Kuskridho Ambardi. (2011). Analisis tentang Perilaku Pemilih Dalam Pemilihan Legislatif Dan Presiden Indonesia Pasca Orde Baru.

Mujani, Saiful, R. William Liddle, dan Kuskridho Ambardi. (2012). Kuasa Rakyat. Jakarta : Mizan Publika.

Niemi, Richard G., Herbert F. Weisberg. (1984). Controversies of Voting Behavior. Washington D.C.: A Division of Congressional Quarterly Inc., 1984.

Pamungkas, Sigit. (2012). Pemilu, Perilaku Pemilih \& Kepartaian. Institute for Democracy and Welfarism (IDW). Yogyakarta : Perum Griya Saka Permai.
Plano, Jack. (1985). Kamus Analisa Politik. Jakarta: Rajawali Press.

Pomper, Gerald. (1978). Voters Choice: Variaties of American Electoral Behavior. New York: Dod, Mead Company. hal 195-208.

Raffiudin, Riaty, dkk. 2012. Teori Politik. Banten : Universitas Terbuka Kementerian Pendidikan dan Kebudayaan.

Sahab, Ali. 2012. Vote Buying dalam Pemilihan Kepala Daerah (Pilkada) Studi Kasus Pilkada Surabaya dan Pilkada Kabupaten Blitar Tahun 2010. Jurnal Jejaring Administrasi Publik Universitas Airlangga. Th II. Nomor 8, JuliDesember.

Sitepu, P. Anthonius.(2007). Dalam Politik Identitas dan Pencitraan Kandidat Gubernur terhadap Perilaku Pemilih. Jurnal Politik Universitas Nasional. VOL. 12 No. 01. 2016.

Surbakti, Ramlan. (2007). Memahami Ilmu Politik. Jakarta : PT Grasindo.

Tim Peneliti KPU Kabupaten Bondowoso. (2015). Laporan Riset Partisipasi Masyarakat dalam Pemilu di Tingkat KPU Kabupaten Bondowoso dengan Tema Perilaku Pemilih.

Umpu, Canang Bagus Prahara. (2017). Hubungan Faktor Sosial Ekonomi Dan Perilaku Politik Uang Terhadap Partisipasi Pemilih Pada Pileg 2014 di Kabupaten Pesisir Selatan.

Wicaksono, Adhi Putra. (2009).

Perilaku Pemilih dalam Pemilihan Kepala Daerah Langsung, Studi 
NUSANTARA : Jurnal Ilmu Pengetahuan Sosial - Vol. 6 No 1 (2019) (Januari - Juni )

issn online : $2550-0813$ issn cetak : $2541-657 \mathrm{X}$

http://jurnal.um-tapsel.ac.id/index.php/nusantara

Penelitian pada Pemilihan

Gubernur/Wakil Gubernur Jawa

Tengah Tahun 2008.

Zetra, Aidinil, Bakaruddin Rosyidi, Ferra Yanuar, Canang Bagus Prahara Umpu. (2015). Partisipasi Politik dan Politik Uang dalam Pemilu Legislatif 2014 di Kabupaten Pesisir Selatan.

Politik Identitas Mengubur Rasionalitas Pemilih. https://nasional.kompas.com/read/201 7/05/03/21150201/politik.identitas.me ngubur.rasionalitas.pemilih diakses pada 18 Maret 2018 pukul 19.59 WIB.

Undang-Undang Nomor 8 Tahun 2015 tentang Perubahan Atas Undang-Undang Nomor 1 Tahun 2015 tentang Penetapan Peraturan Pemerintah Pengganti UndangUndang Nomor 1 Tahun 2014 tentang Pemilihan Gubernur, Bupati dan Walikota Menjadi Undang-Undang.

Peraturan Komisi Pemilihan Umum Nomor 8 Tahun 2017 tentang Sosialisasi, Pendidikan Pemilih dan Partisipasi Masyarakat dalam Pemilihan Gubernur dan Wakil Gubernur, Bupati dan Wakil Bupati,dan/atau Walikota dan Wakil Walikota. 